岡山医誌（1993） 105，903９18

\title{
急性白血病寛解導入療法における 骨髄内白血病細胞減少動態に関する研究
}

岡山大学医学部第二内科学教室（指導：木村郁郎教授）

竹内 誠

(平成 5 年 8 月 17 日受稿)

Key words : acute leukemia, leukemic cell destruction curve, leukemic cell destruction kinetics, remission induction chemotherapy

\section{緒}

言

近年，急性白血病における治療成績の進歩は 著しく，その治療目的は完全寛解 $(\mathrm{CR})$ 率の上 昇, 生存期間の延長から治療を指向した治療体 系の確立へと移行し，現在化学療法により急性 非リンパ性白血病 (ANLL) では30〜40\%"，急 性リンパ性白血病 (ALL) では20３0\%に22治瘾 が期待されている。これら治療成績向上の背景 には, cytosine arabinoside (ara-C $)^{3)}$, daunorubicin $(D N R)^{4)}$ を始め behenoyl ara- $\mathrm{C}^{5)}$, aclarubicin $(\mathrm{ACR})^{6}$, mithoxantrone (MIT $)^{7}$,

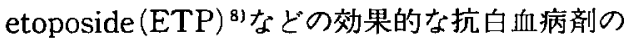
開発と, 臨床応用が大きな比重を占めているこ とは言うまでもないが, Skipperらのの "Total Cell Kill" の理念を基盤とした多剂併用療法の 考案に始まり, 宇塚ら ${ }^{10} の$ DCMP2 段療法等に みられる投与スケジュールの改良, 交叉耐性の ない薬郕を併用した寞解後地固め療法の導

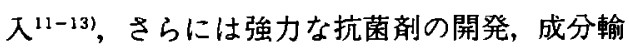
血法の進歩，また顆粒球コロニ一刺激因子 (G$\mathrm{CSF})^{14)}$ ，マクロファージコロニ刺激因子(M -CSF $)^{15)}$ を始めとする各種サイトカインの臨床応 用による補助療法の進歩があることは言うまで もない。すでに周知の如く悪性腫場の化学療法 は「宿主一腫瘍一抗癌剂」の相互関係を前提と したものであり，急性白血病の寛解導入療法に おいては，骨䯣を高度の低形成に至らしめるへ く的確な "responce oriented individualized chemotherapy"16)を行うことが必要とされる.
そのためには抗白血病剤の選択と投与量及び投 与期間の設定が骨蹎内白血病細胞の動態をより 客観的に反映し，設定されることが要求され， さらに抗白血病剂投与時の正常骨䯇細胞の減少 動態が客観的に把握されることが必要と思われ る。同時にまたこれら白血病細胞と正常骨娟道細 胞動態の解析は寛解後地固め療法の投与スケジ ュールの設定,さらにまた寛解導入不能例に对 する salvage 療法の設定に際しても極めて重要 な情報を提供するものと考えられる。

さて，放射線あるいは化学療法後の腫瘍動態 についてはこれまで実験腫痬を中心として検討 され逆 $\mathrm{S}$ 字状曲線を描きつつその効果が発現す ることが報告されているが(7)，臨床面では腫瘍 volumeの定量に制限があり, 白血病細胞数の減 少という意味でその把握が比較的容易である急 性白血病においても化学療法効果を数式的に解 析することは困難とされてきた，本研究におい て著者はすでに実験腫瘍において確認されてい る逆 S字状曲線のモデル式を設定することによ $\eta$ 、臨床的な実測值から初回筧解導入潦法中の 骨髄内白血病細胞の減少動態を数式化し，骨䯣 内白血病細胞減少動㦔と治療効果, 白血病病型, 寞解導入療法，予後との関連を明らかにすると ともに，寛解遒入潦法中の正常骨随細胞減少動 態として骨䯣内赤芽球減少動態を検討すること によって急性白血病治療体系の確立への一助と せんとした。 


\section{研究対象及び研究方法}

1. 研 究 対 象

昭和51年から昭和 61 年までに岡山大学第 2 内 科及び関連病院にて初回寛解導入療法を行った 成人 ANLL 60例 [男女比 $43: 17$, 年龄構成 15－75歳 (中央值40歳)]を対象とした。病型は FAB 分類 ${ }^{18)}$ で M1 12例, M2 31例, M3 5 例, M4 2 例， M5 10例，寛解導入療法としては NCMP [neocarzinostatin (NCS), ara-C, 6mercaptopurine (6-MP), prednisolone (PSL) ] 䝤法が14例, DCMP(DNR, ara-C, 6-MP, PSL) 潦法が17例，BHAC-DMP[DNR, behenoyl ara $-\mathrm{C}$ (BHAC)，6-MP, PSL] 潦法が15例, AC [ACR, ara-C] 燎法が 8 例, BHAC-AMP (ACR, BHAC, 6-MP, PSL) 療法が 2 例, NCDP (NCS, ara-C, DNR, PSL) 燎法が 2 例, DCV (DNR, ara-C, vincristine) 㙩法が 2 例に行われ，完全寞解 (CR) 例は40例，非寞 解 (NR) 例は20例であった。竟解導入療法中骨 髄第刺は原則として，治療前，4，7，11，14 H目に胸骨にて施行し, May-Giemsa 染色標本
を用い500個分類を行い，有核細胞数に白血病細 胞の比率を乘じて白血病細胞数を算出した。な お，CR は木村の判定基準 ${ }^{19} に$ 従った。

2. 研究方法：骨髄内白血病細胞減少曲線の作 成

L. Norton ら ${ }^{17)}$ は化学療法に対する腫瘍の反 応を数理学的に解析し，その反応は腫瘍容量の 大きい時と小さい時低く，中等量腫湯容量で高 くなることを報告しているが，急性白血病にお いても白血病細胞は化学療法開始後, 次第に減 少速度を増して最大減少速度に達し，その後溸 次速度は低下し減少停止に至る様式をとると考 えられる.ここで化学療法開始後の時間(日数) $\mathrm{t}$ に対する腫瘍の容量を $Z$ とし片対数グラフ上 で $Z$ を $t$ 関数,

$$
\log Z=N(t)
$$

と表現する.この関数を減少開始 $\left(t=t_{0}\right)$ から 減少停止 $\left(t=t_{\max }\right)$ までの閉区間で考えれば, $N(t)$ は $n$ 次の $t$ の多項式で近似させること ができる. 急性白血病診断時点で白血病細胞は 堌殖の plateauに達していると仮定すると，化 学䝤法開始時の減少速度は 0 であり,さらに減

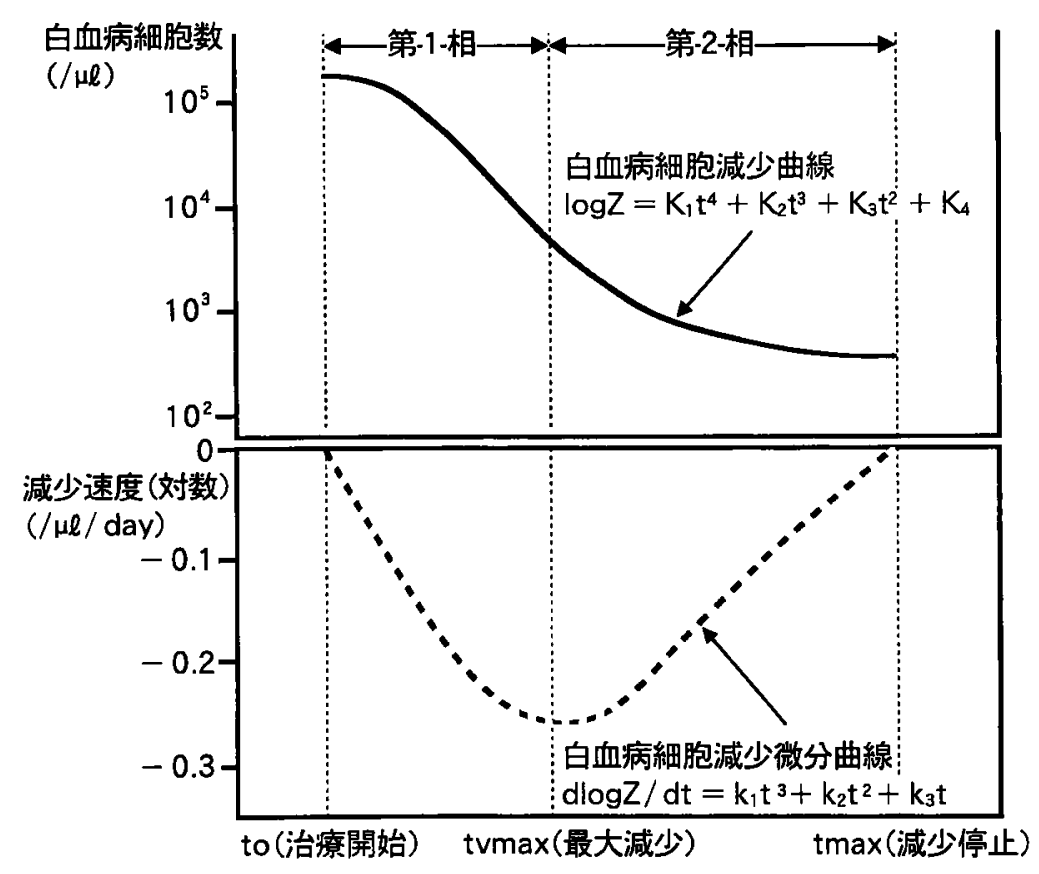

図 1 骨喵内白血病細胞減少曲線 
表 1 骨髄内白血病細胞減少曲線各パラメーター間の相関関係

\begin{tabular}{|c|c|c|c|c|c|c|c|}
\hline & (1) & (2) & (3) & (4) & (5) & (6) & (7) \\
\hline (1) 第一相の期間 & & 0.627 & 0.653 & -0.415 & -0.415 & 0.841 & -0.278 \\
\hline (2) 第二相の期間 & & & 0.411 & -0.577 & -0.285 & 0.949 & -0.473 \\
\hline $\begin{array}{l}\text { (3) 第一相の平均 } \\
\text { 減少加速度 }\end{array}$ & & & & -0.773 & -0.860 & 0.553 & 0.245 \\
\hline $\begin{array}{c}\text { (4) 第二相の平均 } \\
\text { 減少加速度 }\end{array}$ & & & & & -0.807 & -0.572 & -0.123 \\
\hline (5) 最大減少速度 & & & & & & 0.370 & 0.544 \\
\hline (6) 減少停止日 & & & & & & & -0.437 \\
\hline $\begin{array}{l}\text { (7) 減少停止時 } \\
\text { 白血病細胞数 }\end{array}$ & & & & & & & \\
\hline
\end{tabular}

第 1 相の期間

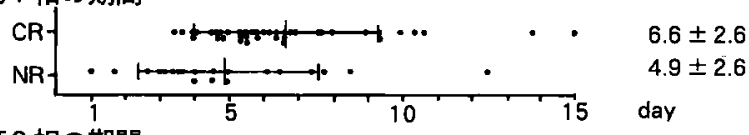

－第2 相の期間

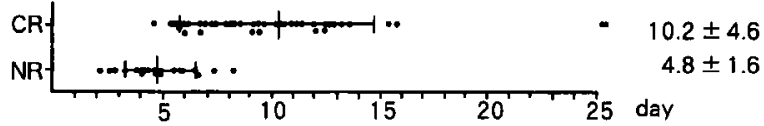

第 1 相の平均減少加速度

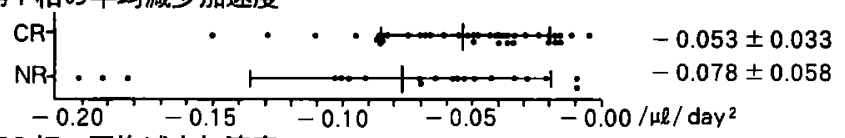

第 2 相の平均減少加速度

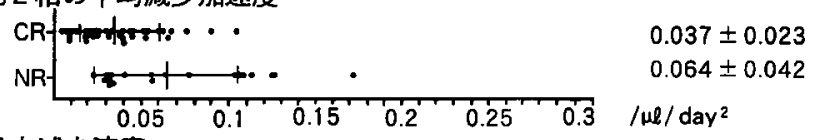

最大減少速度

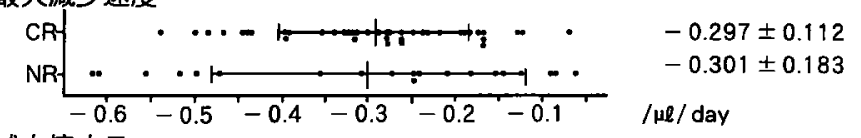

減少停止日

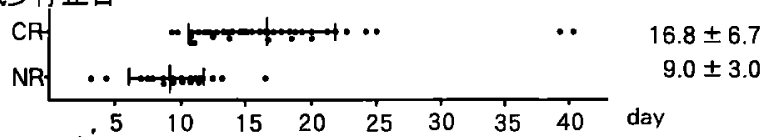

残存白血病細胞数

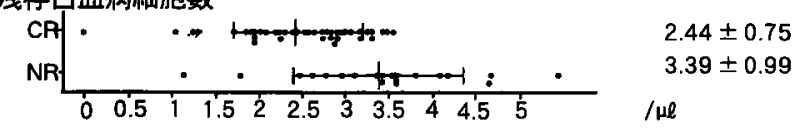

图 $2 \mathrm{CR}$ 例と NR 例における骨㵦内白血病細胞減少曲線各パラメーターの比較 
少停止時の減少速度は 0 であるから，

に分けて呼ぶことにする。既に正岡ら ${ }^{201}$ は第二相

$$
\begin{aligned}
& \mathrm{d} N\left(t_{0}\right)=0 \\
& \mathrm{~d} N\left(t_{\max }\right)=0
\end{aligned}
$$

となる．以上より $\mathrm{d} N(t) / \mathrm{d} t$ は閉区間内で最大 の $\mathrm{N}(t)$ に二次曲線をあてはめ近似できること を解析している。即ち第二相における $\mathrm{d} N(t) /$ $\mathrm{d} t$ は直線に近い動きをすると考之られ, 全経過 減少速度到達時 $t_{\mathrm{vmax}}\left(t_{0}<t_{\mathrm{vmax}}<t_{\text {max }}\right)$ に極小値 を通じての減少速度のモデル式は，しだいに減 を持つような曲線で描くことができる。

ここで閉区間を減少開始より最大減少到達時 少速度を增して最大減少速度に達する第一相と, 比較的直線的に速度を落とし減少停止に至る第 までの第一相とそこより減少停止までの第二相
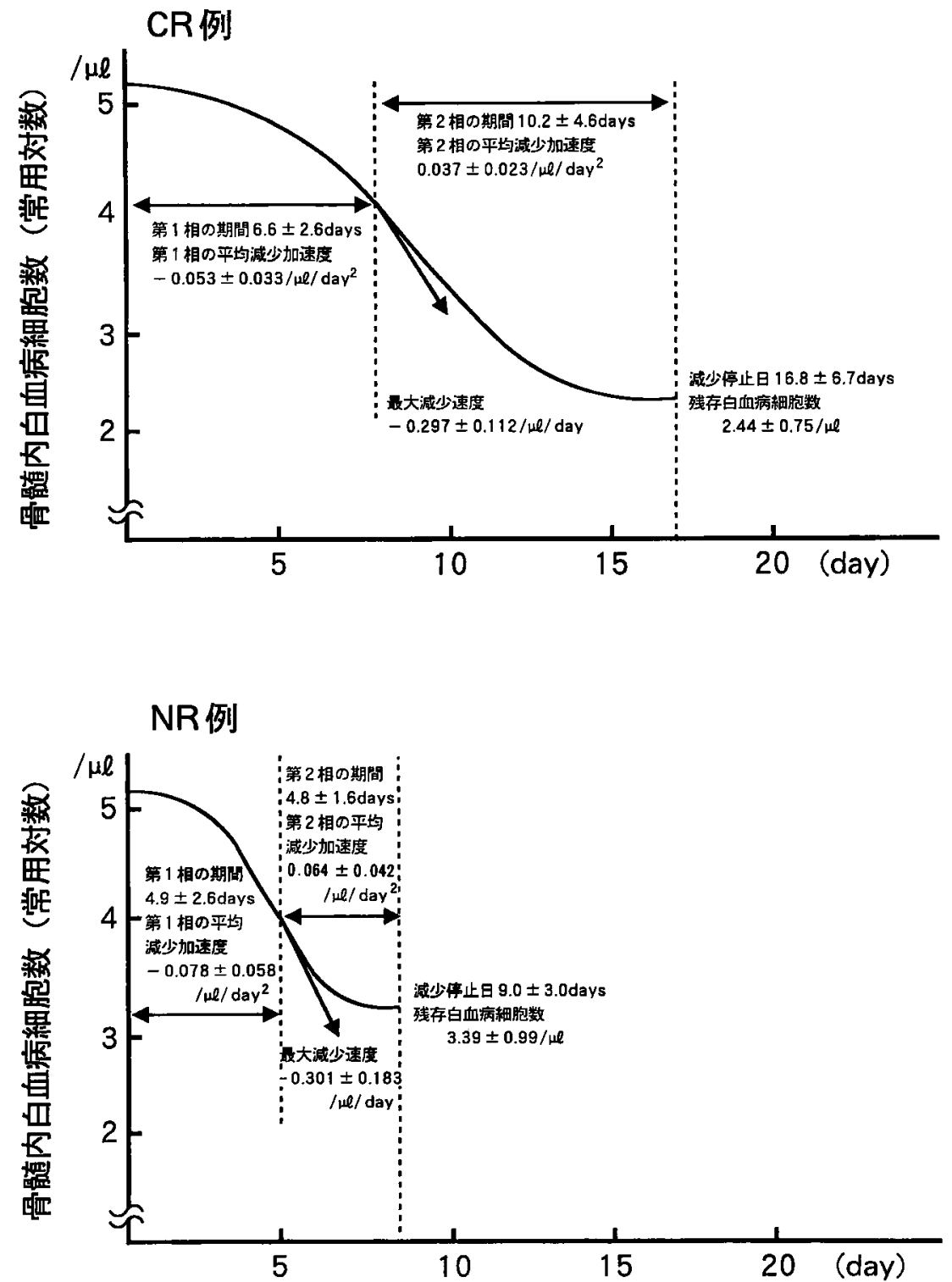

図 3 CR 例と NR 例における骨鲔内白血病細胞減少曲線の比較 
非対称形の曲線である必要が想定され，この条 件を满たす式のうち最も低次である 3 次式を設 定した. [2] を满たすモデル式は

$$
\mathrm{d} N(t)=k_{1} t^{3}+k_{2} t^{2}+k_{3} t
$$

で表され，曲線は図1の破線のようになる，減 少速度の実測值としては平均値の定理より, 各 測定值間を結ぶ直線の傾きをその中点における 曲線の傾きの近似値とし,最小 2 乗法により [4] の係数を決定した。さらに閉区間内においてこ の式を積分することにより骨䯣内白血病細胞数 を表す式

$$
\log Z=K_{1} t^{4}+K_{2} t^{3}+K_{3} t^{2}+K_{4}
$$

が得られ，曲線は図1の実線のようになり，こ の区間の骨髄内白血病細胞の実測值から再度, 最小 2 乗法により［5］の各俰数を決定した.

骨髄内白血病細胞減少動態の解析はこの式上 $\eta$ 得られる第一相, 第二相の日数及びその期間 における平均減少速度, 最大減少速度, 第二相 の終わりである減少停止日, 減少停止時残存白 血病細胞数をパラメータとして解析を行った. また，寞解導入療法中の骨䯣正常細胞の減少動 態を解析すへくく骨䐈内赤芽球の減少動態に対し ても白血病細胞に对して用いた減少曲線を適用 し解析した。

なお，以下に示す骨骾内白血病細胞数及び骨 骵内赤芽球細胞数はすへで常用対数で表した.

\section{研 究 成 績}

1.急性非りンパ性口血病寞解導入軞法におけ る骨髄内向血病細胞減少動態の検討

（1）白血病細胞減少曲線の実測值に対する決 定係数及U゙各パラメーターの独立性の検 討

今回作成した骨䯣内白血病細胞減少曲線の白 血病細胞実測值に对寸る決定係数 [1-(残差 2

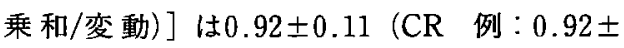
0.08 , NR 例 : $0.92 \pm 0.15)$ であった.

今回検討した 7 項目のパラメーターにつき相 互関係を表 1 に示した。第一相，第二相の日数 と減少停止日との間，第一相平均減少加速度と 最大減少速度との間に強い相関関係がみられた ことは減少停止日が第一相, 第二相の期間の和 であること，さらには加速度と速度の関係から 当然であるが, 第一相平均減少加速度及び最大 減少速度と第二相平均減少加速度との間にも負 の相関関係を認めた。その他のパラメーターは おおむ独立したパラメーターであった。

(2) 治療効果別骨髄内白血病細胞減少曲線の 検討

$\mathrm{CR}$ 例40例と NR 例20例の減少曲線各パラメ 一ターについての比較を図 2 に示した。第一相 の月数は CR 例で $6.6 \pm 2.6$ days, NR 例で $4.9 \pm$ 2.6 days と有意 $(\mathrm{p}<0.05)$ に $\mathrm{C}$ 例で長かっ

\begin{tabular}{|c|c|c|c|c|c|c|c|}
\hline $\begin{array}{l}\text { CR 例 } \\
(n=40)\end{array}$ & $\begin{array}{c}\text { 第一相の } \\
\text { 期 間 } \\
\text { (days) }\end{array}$ & $\begin{array}{c}\text { 第二相の } \\
\text { 期 間 } \\
\text { (days) }\end{array}$ & $\begin{array}{c}\text { 第一相 } の \text { 平均 } \\
\text { 減少加速度 } \\
\left(/ \mu \ell / \mathrm{day}^{2}\right)\end{array}$ & $\begin{array}{l}\text { 第二相の平均 } \\
\text { 減少加速度 } \\
\left(/ \mu \ell / \mathrm{day}^{2}\right)\end{array}$ & $\begin{array}{c}\text { 最大減少速度 } \\
(/ \mu \ell / \text { day })\end{array}$ & $\begin{array}{c}\text { 減少停止日 } \\
\text { (days) }\end{array}$ & $\begin{array}{r}\text { 減少停止時 } \\
\text { 白血病細胞数 } \\
(/ / \mu \ell)\end{array}$ \\
\hline M1 $(n=5)$ & $9.5 \pm 4.5$ & $16.8 \pm 8.0$ & $-0.026 \pm 0.017$ & $0.015 \pm 0.009$ & $-0.192 \pm 0.079$ & $26.3 \pm 12.5$ & $2.04 \pm 1.24$ \\
\hline M2 $(n=22)$ & $6.0 \pm 1.9$ & $8.9 \pm 2.5$ & 30 & 18 & $-0.291 \pm$ & $14.9 \pm 3.9$ & $2.70 \pm 0.60$ \\
\hline M3 $(n=3)$ & $5.9 \pm 0.7$ & $10.8 \pm 2.4$ & & & $-0.400 \pm 0$ & $16.7 \pm 3.1$ & $1.54 \pm 0.72$ \\
\hline M4 $(n=2)$ & $8.0 \pm 1.7$ & $13.8 \pm 2.7$ & $-0.029 \pm 0.015$ & $0.016 \pm 0.008$ & $-0.218 \pm 0.068$ & $21.8 \pm 4.4$ & $2.62 \pm 0.32$ \\
\hline M5 $(n=8)$ & $6.2 \pm 2.4$ & $8.5 \pm 3.6$ & $667 \pm 0.048$ & $0.052 \pm 0$ & $-0.360 \pm 0$ & $14.6 \pm 4.8$ & $2.27 \pm 0.52$ \\
\hline $\begin{array}{l}\text { NR 例 } \\
(n=20)\end{array}$ & $\begin{array}{c}\text { 第一相の } \\
\text { 期 間 } \\
\text { (days) }\end{array}$ & $\begin{array}{c}\text { 第二相の } \\
\text { 期 間 } \\
\text { (days) }\end{array}$ & $\begin{array}{c}\text { 第一相の平均 } \\
\text { 減少加速度 } \\
\left(/ \mu \ell / \mathrm{day}^{2}\right)\end{array}$ & $\begin{array}{c}\text { 第二相の平均 } \\
\text { 減少扣速度 } \\
\left(/ \mu \ell / \mathrm{day}^{2}\right)\end{array}$ & $\begin{array}{c}\text { 最大減少速度 } \\
(/ \mu \ell / \mathrm{day})\end{array}$ & $\begin{array}{c}\text { 減少停止日 } \\
\text { (days) }\end{array}$ & $\begin{array}{r}\text { 減少停止時 } \\
\text { 白掹病細胞数 } \\
(/ \mu \ell)\end{array}$ \\
\hline M1 $(n=7)$ & $4.5 \pm 1.5$ & $5.1 \pm 1.4$ & $-0.087 \pm 0.053$ & $0.063 \pm 0.033$ & $-0.352 \pm 0.159$ & $9.7 \pm 1.4$ & $3.14 \pm 1.25$ \\
\hline M2 $(n=9)$ & $4.9 \pm 3.5$ & $4.5 \pm 1.8$ & $-0.063 \pm 0.053$ & $0.051 \pm 0.033$ & $-0.228 \pm 0.163$ & 9.5 & $3.80 \pm 0.85$ \\
\hline M3 $(n=2)$ & $4.5 \pm 2.2$ & $4.1 \pm 1.1$ & $-0.193 \pm 0.017$ & $0.148 \pm 0.315$ & $-0.583 \pm 0.040$ & $8.6 \pm 1.1$ & $2.54 \pm 0.09$ \\
\hline M4 $(n=0)$ & - & - & - & - & - & - & - \\
\hline M5 $(\mathbf{n}=2)$ & $6.2 \pm 3.3$ & $5.7 \pm 2.4$ & $-0.037 \pm 0.038$ & $0.028 \pm 0.008$ & $-0.169 \pm 0.111$ & $11.9 \pm 0.8$ & $3.30 \pm 0.30$ \\
\hline
\end{tabular}

表 2 病型別にみた骨䯣内白血病細胞減少曲線各パラメーターの比較 
誠

たが，第一相における平均減少加速度は CR 例

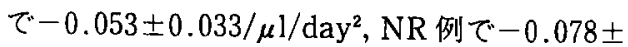
$0.58 / \mu \mathrm{l} / \mathrm{day}^{2}$ と CR 例で小さい傾问を認めるも のの有意差は認めなかった。第二相の日数は $\mathrm{CR}$

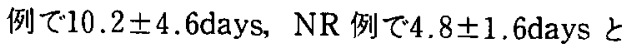
有意（ $\mathrm{p}<0.001 ） に \mathrm{CR}$ 例で長く，さらに第二 相平均娍少加速度も $\mathrm{CR}$ 例で $0.037 \pm 0.023 / \mu 1 /$ $\mathrm{day}^{2}, \mathrm{NR}$ 例で $0.064 \pm 0.042 / \mu 1 / \mathrm{day}^{2}$ と有意差 $(\mathrm{p}<0.001)$ を認めた。最大減少速度は CR 例

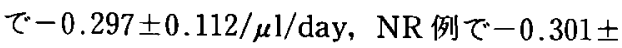
$0.183 / \mu 1 /$ day とほとんど差を認めなかった. 減
少停止までの日数は CR 例で16.8 06.7 days, NR 例で $9.0 \pm 3.0$ days と有意 $(\mathrm{p}<0.001)$ に $\mathrm{CR}$ 例で長かった．減少停止時残存白血病細胞数は $\mathrm{CR}$ 例で2.44 $\pm 0.75 / \mu 1$, NR 例で3.39 $\pm 0.99 /$ $\mu 1$ と $\mathrm{CR}$ 例で有意 $(\mathrm{p}<0.001)$ に減少していた。 以上より $\mathrm{CR}$ 例では $\mathrm{NR}$ 例に比べやや急峻で, より長く減少する曲線が描かれた（図 3 ）。

(3) 病型別骨䯣内白血病細胞減少曲線の検討 $\mathrm{FAB}$ 分類による病型別の各パラメーターを $\mathrm{CR}$ 症例と NR 症例とに分けて比較した（表 2). CR 率は M1 で41.7\%（12例中 5 例)，M2 で71

表 3 治楾法別にみた骨兪道内白血病細胞減少曲線各パラメーターの比較

\begin{tabular}{|c|c|c|c|c|c|c|c|}
\hline CR 例 & $\begin{array}{c}\text { 第一相の期間 } \\
\text { (days) }\end{array}$ & $\begin{array}{c}\text { 第二相の期間 } \\
\text { (days) }\end{array}$ & $\begin{array}{c}\text { 第一相の平均 } \\
\text { 減少加速店 } \\
\left(/ \mu \ell / \text { day }^{2}\right)\end{array}$ & $\begin{array}{l}\text { 第二相の平均 } \\
\text { 娍少加述度 } \\
\left(/ \mu \ell / \mathrm{day}^{2}\right)\end{array}$ & $\begin{array}{c}\text { 最大減少速度 } \\
(/ \mu \ell / \text { day })\end{array}$ & $\begin{array}{c}\text { 減少停止日 } \\
\text { (days) }\end{array}$ & $\begin{array}{r}\text { 減少停止時 } \\
\text { 血病細胞数 } \\
(/ / \mu)\end{array}$ \\
\hline$(n=9)$ & $7.9 \pm 3.1$ & $11.0 \pm 6.1$ & $-0.040 \pm 0.025$ & $0.030 \pm 0.015$ & $-0.251 \pm 0.086$ & $18.9 \pm 8.6$ & $2.74 \pm 0.47$ \\
\hline DCMP $\quad(n=11)$ & $5.8 \pm 1.7$ & $9.7 \pm 3.0$ & $-0.064 \pm 0.046$ & $0.039 \pm 0.028$ & $-0.314 \pm 0.145$ & $15.5 \pm 4.5$ & $2.57 \pm 0.76$ \\
\hline BHAC-DMP $(n=11)$ & $6.3 \pm 2.2$ & $9.6 \pm 3.4$ & $-0.058 \pm 0.032$ & $0.037 \pm 0.017$ & $-0.311 \pm 0.106$ & $16.0 \pm 4.7$ & $2.30 \pm 0.75$ \\
\hline $\mathrm{AC} \quad(\mathrm{n}=4)$ & $5.1 \pm 0.4$ & $9.0 \pm 1.0$ & $-0.062 \pm 0.019$ & $0.035 \pm 0.013$ & $-0.306 \pm 0.074$ & $14.0 \pm 1.4$ & $2.54 \pm 0.42$ \\
\hline $\operatorname{BHAC}-\mathrm{AMP}(\mathrm{n}=2)$ & $9.8 \pm 7.3$ & $15.6 \pm 13.6$ & $-0.048 \pm 0.052$ & $0.037 \pm 0.042$ & $-0.286 \pm 0.158$ & $25.4 \pm 20.9$ & $1.07 \pm 1.58$ \\
\hline$D C V \quad(n=2)$ & $6.0 \pm 0.4$ & $7.4 \pm 4.2$ & $-0.055 \pm 0.029$ & $0.062 \pm 0.061$ & $-0.334 \pm 0.194$ & $13.4 \pm 3.8$ & $2.41 \pm 0.68$ \\
\hline NR 例 & $\begin{array}{c}\text { 第一相の期間 } \\
\text { (days) }\end{array}$ & $\begin{array}{c}\text { 第二相の期間 } \\
\text { (days) }\end{array}$ & $\begin{array}{l}\text { 第一相の平均 } \\
\text { 減少加述度 } \\
\left(/ \mu \ell / \mathrm{day}^{2}\right)\end{array}$ & $\begin{array}{l}\text { 第二相の平均 } \\
\text { 減少加速度 } \\
\left(/ \mu \ell / \mathrm{day}^{2}\right)\end{array}$ & $\begin{array}{c}\text { 最大減少速度 } \\
\text { (/ } / \text { L /day })\end{array}$ & $\begin{array}{c}\text { 減少僄止日 } \\
\text { (days) }\end{array}$ & $\begin{array}{r}\text { 減少停止時 } \\
\text { 血病細胞数 } \\
(/ \mu \ell)\end{array}$ \\
\hline$(n=5)$ & $4.1 \pm 2.2$ & $4.6 \pm 1.7$ & $-0.074 \pm 0.034$ & $0.057 \pm 0.030$ & $-0.284 \pm 0.169$ & $8.9 \pm 3.3$ & $3.22=0.32$ \\
\hline DCMP $\quad(n=6)$ & $5.1 \pm 2.1$ & $5.2 \pm 1.3$ & $-0.069 \pm 0.064$ & $0.051 \pm 0.034$ & $-0.268 \pm 0.177$ & $10.4 \pm 2.0$ & $3.25 \pm 0.94$ \\
\hline BHAC-DMP $(n=4)$ & $3.5 \pm 1.8$ & $4.1 \pm 1.3$ & $-0.135 \pm 0.076$ & $0.110 \pm 0.058$ & $-0.467 \pm 0.158$ & $7.6 \pm 2.1$ & $2.72 \pm 1.47$ \\
\hline$A C \quad(n=4)$ & $6.7 \pm 4.3$ & $4.2 \pm 4.3$ & $-0.045 \pm 0.026$ & $0.057 \pm 0.034$ & $-0.217 \pm 0.079$ & $11.2 \pm 3.8$ & $3.84 \pm 0.33$ \\
\hline
\end{tabular}

表 4 年秢別にみた骨䯣内白血病細胞減少曲線各パラメーターの比較

\begin{tabular}{|c|c|c|c|c|c|c|c|}
\hline $\begin{array}{l}\text { CR 例 } \\
(n=40)\end{array}$ & $\begin{array}{c}\text { 第一相の } \\
\text { 期 間 } \\
\text { (days) }\end{array}$ & $\begin{array}{c}\text { 第二相の } \\
\text { 期 間 } \\
\text { (days) }\end{array}$ & $\begin{array}{c}\text { 第一相の平均 } \\
\text { 減少加速度 } \\
\left(/ \mu \ell / \mathrm{day}^{2}\right)\end{array}$ & $\begin{array}{c}\text { 第二相の平均 } \\
\text { 減少加速度 } \\
\left(/ \mu \ell / \mathrm{day}^{2}\right)\end{array}$ & $\begin{array}{c}\text { 最大減少速度 } \\
(/ \mu \ell / \text { day })\end{array}$ & $\begin{array}{c}\text { 減少停止日 } \\
\text { (days) }\end{array}$ & $\begin{array}{r}\text { 娍少停止時 } \\
\text { 白血病細胞数 } \\
(/ \mu \ell)\end{array}$ \\
\hline $\begin{array}{l}\text { 高魿者 } \\
(60 \text { 歲以上 } \\
(n=3)\end{array}$ & $9.9 \pm 4.0$ & $14.2 \pm 9.9$ & $-0.021 \pm 0.015$ & $0.020 \pm 0.170$ & $-0.172 \pm 0.090$ & $24.1 \pm 13.0$ & $2.86 \pm 0.11$ \\
\hline $\begin{array}{l}\text { 非高略者 } \\
(60 \text { 歳未満 }) \\
(\mathrm{n}=37)\end{array}$ & $6.3 \pm 2.3$ & $9.8 \pm 3.9$ & $-0.057 \pm 0.034$ & $0.049 \pm 0.070$ & $-0.307 \pm 0.109$ & $16.2 \pm 5.9$ & $2.39 \pm 0.76$ \\
\hline $\begin{array}{l}\text { NR 例 } \\
(n=20)\end{array}$ & $\begin{array}{c}\text { 第一相の } \\
\text { 期 間 } \\
\text { (days) }\end{array}$ & $\begin{array}{c}\text { 第二相の } \\
\text { 期 間 } \\
\text { (days) }\end{array}$ & $\begin{array}{c}\text { 第一相の平均 } \\
\text { 減少加速度 } \\
\left(/ \mu \ell / \text { day }^{2}\right)\end{array}$ & $\begin{array}{c}\text { 第二相の平均 } \\
\text { 減少加速度 } \\
\left(/ \mu \ell / \text { day }^{2}\right)\end{array}$ & $\begin{array}{c}\text { 最大減少速度 } \\
(/ \mu \ell / \text { day })\end{array}$ & $\begin{array}{c}\text { 減少停止日 } \\
\text { (days) }\end{array}$ & $\begin{array}{r}\text { 減少停止時 } \\
\text { 白血病練胞数 } \\
(/ \mu \ell)\end{array}$ \\
\hline 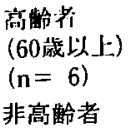 & $4.6 \pm 2.6$ & $4.5 \pm 1.4$ & $-0.055 \pm 0.037$ & $0.044 \pm 0.032$ & $-0.212 \pm 0.167$ & $9.5 \pm 3.3$ & $3.80 \pm 0.92$ \\
\hline $\begin{array}{l}\text { (60减未満) } \\
(\mathrm{n}=14)\end{array}$ & $4.9 \pm 2.7$ & $4.9 \pm 1.7$ & $-0.088 \pm 0.063$ & $0.073 \pm 0.044$ & $-0.339 \pm 0.182$ & $9.9 \pm 2.9$ & $3.22 \pm 1.00$ \\
\hline
\end{tabular}


\% (31例中22例)，M3 で60\%（5例中 3 例)， M 4 で100\%（2 例中 2 例), M5 で80\%（10例 中 8 例) であった。病型間で症例数に偏りがあ るが, 病型間には各パラメーターに差は認めな かった.

（4）寛解導入療法別骨髄内白血病細胞減少曲 線の検討

$\mathrm{CR}$ 症例及U゙ NR 症例で寛解導入療法別に各 パラメーターを比較した（表 3 ). CR 症例は 2 例以上の CR 例が得られた NCMP（14例中 9 例, 64.3\%)，DCMP (17例中11例，64.7\%), BHCA-DMP (15例中11例, 73.3\%), AC (8 例中 4 例, $50 \%$ ), BHAC-AMP（2例中 2 例， $100 \%), \operatorname{DCV}(2$ 例中 2 例，100\%)の 6 療法に おいて，また，NR 症例は 2 例以上の NR 例の ある NCMP, DCMP, BHAC-DMP, ACの 4 療法で各パラメーターを検討したが，その結果
は表 3 に示すように，各治療法間で各パラメー ターにおける差は認められなかった。

（5）年齢別骨髄内白血病細胞減少曲線の㭘討

$\mathrm{CR}$ 症例及び NR 症例をそれぞれ60歳以上の 高㱓者群と60歳末満の非高齢者群とに分けて各 パラメーターを検討した. CR 率は高粭者群で 9 例中 3 例 $(33.3 \%)$, 非高齢者群で51例中 37 例 (72.5\%) であった，症例数に偏りがあるが， 表 4 に示寸ように CR 症例において高齢者群で は第一相の期間が長く $(p<0.05)$, 最大減少速

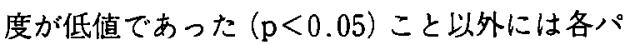
ラメーターにおける差はみられなかった。

2 、急性非リンパ性白血病寛解導入療法に扔け る骨跹内赤芽球減少動態の㭘討

（1）治療効果別骨髄内赤芽球減少曲線の検討 化学療法に伴う骨髄正常細胞の減少動態の指 標として今回検討した60例のうち47例(CR 31例，

一 第 1 相の期間

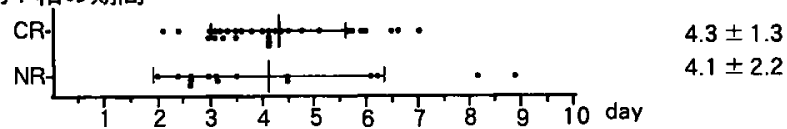

第 2 相の期間

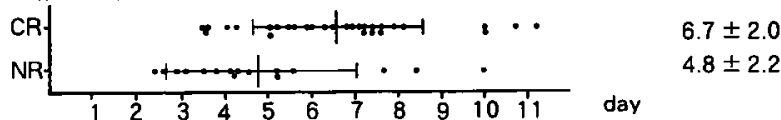

第 1 相の平均隇少加速度

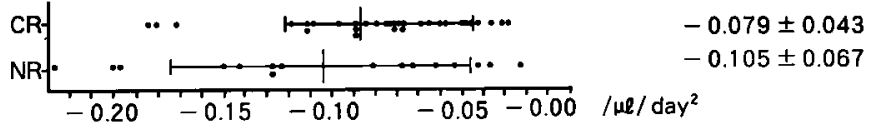

> 第2 相の平均減少加速度

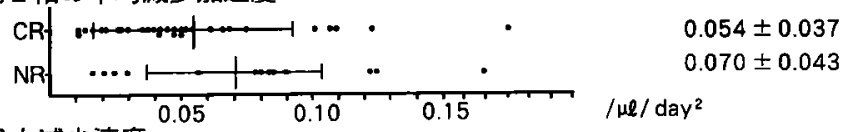

最大減少速度

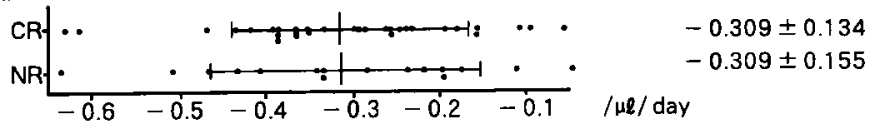

減少停止日

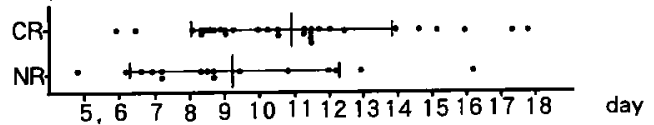

$10.9 \pm 2.9$

$9.2 \pm 3.0$

残存細胞数

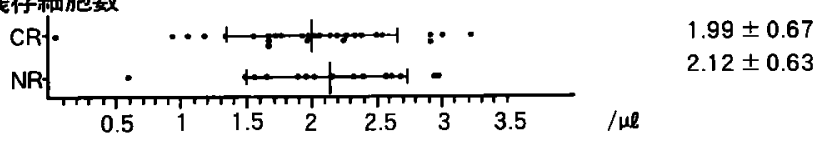

図 $4 \mathrm{CR}$ 例と NR 例に扮ける骨髄内赤芽球減少曲線各パラメーターの比較 
NR 16例）につき寞解導入療法中の骨髄内赤芽 球の減少動態を白血病細胞に対して適用した減 少曲線を用いて解析した. 実測值に対する決定 係数は $0.84 \pm 0.19$ (CR 例0.82 \pm 0.21 , NR 例 $0.87 \pm 0.14 ＼mathrm{~ て ゙ あ っ た . ~ C R ~ 例 と ~ N R ~ 例 を 比 較 ~}$ したところ図 4 に示すように CR 例で第二相の 期間が長かったが $(p<0.01)$ ，その他のパラメ ーターには治療効果による差を認めなかった.

（2）年齢別骨䯣内赤芽球減少曲線の検討 高齢者と非高齢者の骨咀正常細胞の減少動態 の違いを検討する目的で，骨蹃内赤芽球減少曲 線を解析した47例を治療効果別に60歳以上の高 齢者群（CR 3 例，NR 5 例）と60歳末満の非高 齢者群 (CR28例，NR11例）とに分けて検討し たところ，表 5 に示すように両群間に各パラメ ーターにおける差を認めなかった。

3 . 白血病細胞減少動態と予後の関連

CR 中早期に合併症にて死亡した 3 例と追跡不 能例 1 例を除く CR 症例36例を対象に骨䯣内白 血病細胞減少曲線を予後との関連について検討 した.まず, $\mathrm{CR}$ 持続期間 2 年以上の長期 $\mathrm{CR}$ 持 続群12例と 2 年未満の早期再発群24例とに分け て検討した結果，図 5 に示すように長期 CR 持 続群では早期再発群に比へ，第二相平均減少加 速度が小さい傾向が認められた。第二相平均減 少加速度を高值群 [平均値十標準偏差值以上 $(7$
例)， 中間值群（平均値十標準偏差値未満で平 均值一標準偏差值以上 (25例) ], 低值群 (平均 値一標準偏差値未満 (4 例) ] の 3 群に分けて初 回筧解持続期間及び生存期間について検討した ところ図6，7に示すように高値群において初 回寛解持続期間，生存期間共に短い傾向がみら れた.

\section{考察}

急性白血病の治療においては, 診断時点で $10^{12}$ 個以上存在する白血病細胞を減少させ, 正常造 血細胞の回復をもって完全寛解に到達させるこ とが第一目標であり，またこのことが長期生存 を得るための最も重要な要因である，骨髄内白 血病細胞は抗白血病剤投与により減少するが， その減少動癿はいまだ十分に解明されたとは言 い難い. Norton ら ${ }^{17}$ は実験腄瘍において化学療 法効果は逆 S 字状曲線を描きつつ発現すること を確認しており，また化学療法による白血病細 胞の減少動態につき, Hart ら ${ }^{21}$ は exponential な減少を示すとし, Presant ${ }^{22)} ら は$ Azacytidine 投与マウス L1210白血病において Colony Forming Unit は当初急速に減少し，その後緩徐に減 少するといった二相性を示すことを明らかにし ている。正岡ら ${ }^{201}$ は急性白血病寛解導入時の末梢 血及び骨髄中の白血病細胞の減少動態を(1)白血

表 5 年齡別にみた骨喵内赤芽球減少曲楾各パラメーターの比較

\begin{tabular}{|c|c|c|c|c|c|c|c|}
\hline $\begin{array}{l}\text { CR 例 } \\
(n=31)\end{array}$ & $\begin{array}{c}\text { 第一相の } \\
\text { 期 間 } \\
\text { (days) }\end{array}$ & $\begin{array}{c}\text { 第二相の } \\
\text { 期 間 } \\
\text { (days) }\end{array}$ & $\begin{array}{c}\text { 第一相の淡均 } \\
\text { 減少加速度 } \\
\left(/ \mu \ell / \mathrm{day}^{2}\right)\end{array}$ & $\begin{array}{c}\text { 第二相の平均 } \\
\text { 減少加速度 } \\
\left(/ \mu \ell / \mathrm{day}^{2}\right)\end{array}$ & $\begin{array}{c}\text { 最大減少速度 } \\
\text { (/ } \mu \ell / \text { day })\end{array}$ & $\begin{array}{c}\text { 減少停止日 } \\
\text { (days) }\end{array}$ & $\begin{array}{r}\text { 減少停止時 } \\
\text { 白血病細胞数 } \\
(/ \mu \ell)\end{array}$ \\
\hline 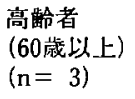 & $4.6 \pm 1.8$ & $8.2 \pm 2.7$ & $-0.052 \pm 0.032$ & $0.029 \pm 0.018$ & $-0.233 \pm 0.136$ & $12.7 \pm 4.5$ & $2.03 \pm 0.42$ \\
\hline $\begin{array}{l}\text { 非高龄者 } \\
(60 \text { 歲未满 }) \\
(n=28)\end{array}$ & $4.2 \pm 1.2$ & $6.5 \pm 2.0$ & $-0.081 \pm 0.043$ & $0.057 \pm 0.038$ & $-0.317 \pm 0.133$ & $10.7 \pm 2.8$ & $1.98 \pm 0.71$ \\
\hline $\begin{array}{l}\text { NR 例 } \\
(n=16)\end{array}$ & $\begin{array}{c}\text { 第一相の } \\
\text { 期 間 } \\
\text { (days) }\end{array}$ & $\begin{array}{c}\text { 第二相の } \\
\text { 期 間 } \\
\text { (days) }\end{array}$ & $\begin{array}{c}\text { 第一相の平均 } \\
\text { 減少加速度 } \\
\left(/ \mu \ell / \text { day }^{2}\right)\end{array}$ & $\begin{array}{c}\text { 第二相の平均 } \\
\text { 減少加速度 } \\
\left(/ \mu \ell / \mathrm{day}^{2}\right)\end{array}$ & $\begin{array}{c}\text { 最大减少速度 } \\
(/ \mu \ell / \mathrm{day})\end{array}$ & $\begin{array}{c}\text { 減少停止日 } \\
\text { (days) }\end{array}$ & $\begin{array}{r}\text { 減少停止時 } \\
\text { 白血病細胞数 } \\
(/ \mu \ell)\end{array}$ \\
\hline $\begin{array}{l}\text { 高齢者 } \\
(60 \text { 噦以上 }) \\
(n=5)\end{array}$ & $3.5 \pm 1.7$ & $4.4 \pm 2.4$ & $-0.012 \pm 0.072$ & $0.075 \pm 0.062$ & $-0.266 \pm 0.145$ & $7.9 \pm 3.1$ & $2.21 \pm 0.51$ \\
\hline $\begin{array}{l}\text { 非高齢者 } \\
(60 \text { 㭰满 } \\
(\mathrm{n}=11)\end{array}$ & $4.3 \pm 2.4$ & $5.0 \pm 2.2$ & $-0.097 \pm 0.067$ & $0.069 \pm 0.038$ & $-0.328 \pm 0.163$ & $9.7 \pm 2.9$ & $2.08 \pm 0.70$ \\
\hline
\end{tabular}


十第1 相の期間

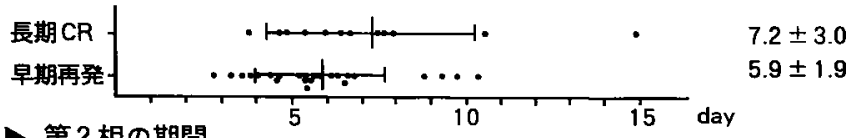

第 2 相の期間

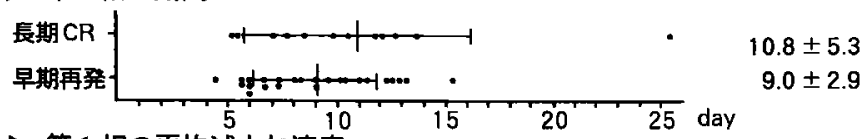

第 1 相の平均隇少加速度

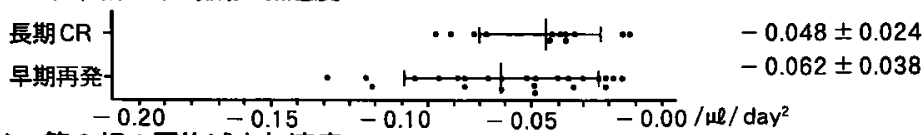

第 2 相の平均減少加速度

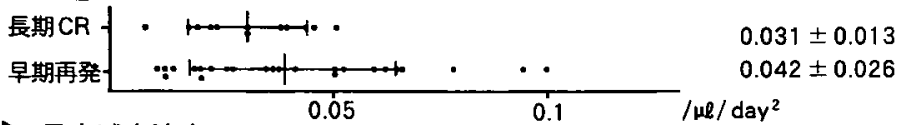

最大減少速度

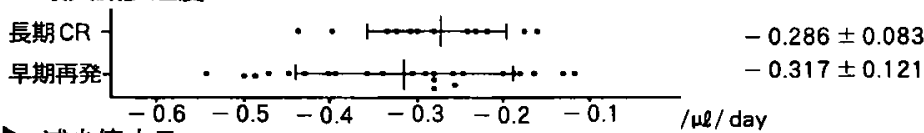

減少停止日

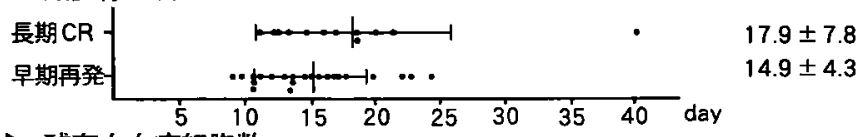

残存白血病細胞数

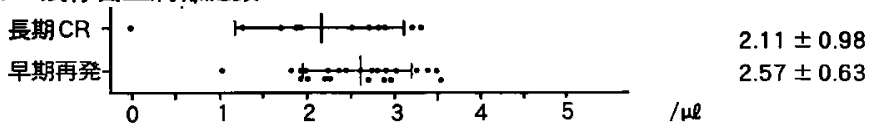

図 5 長期 CR 持続例と早期再発例における骨鹃内白血病細胞減少曲線各パラメーターの比較

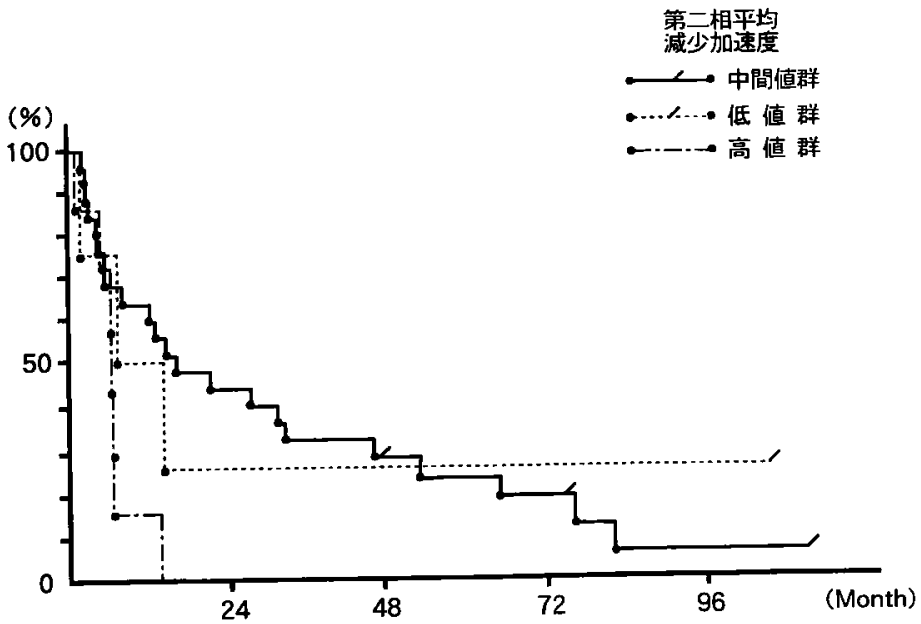

図 6 寛解維持期間 


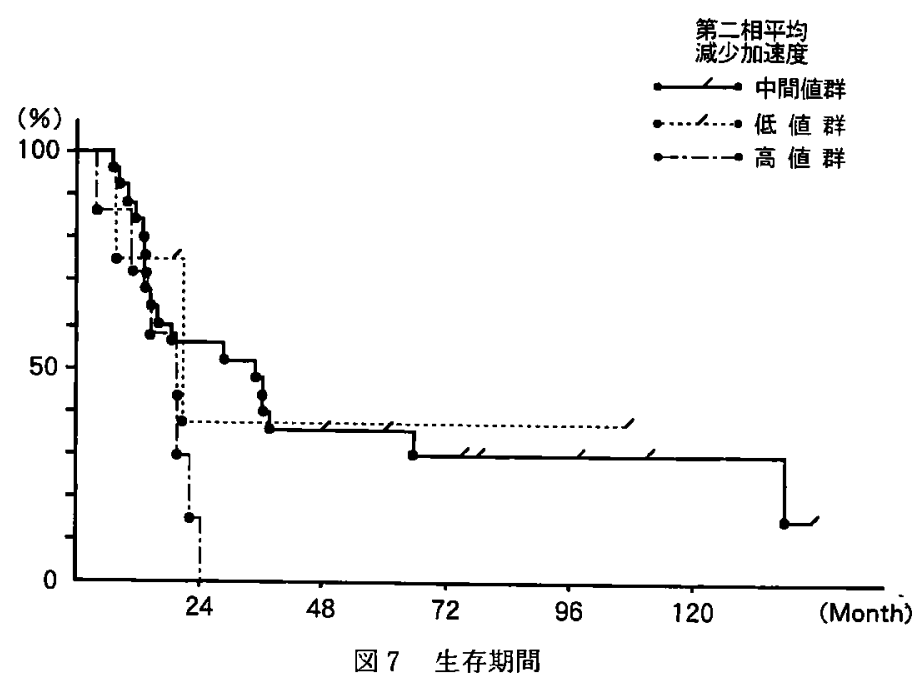

病減少開始から最大減少までの第一相，(2)最大 減少から減少停止までの第二相，(3)減少停止後 一定值に留まる第三相，(4)再び增加に転じる第 四相の 4 期に分け，特に第二相について白血病 細胞減少曲線を 2 次式に近似させ, 「最大減少速 度とその時期」, 「減少速度の低下率」,「減少停 止時期」,「減少停止時残存白血病細胞数」など を検討した結果，残存白血病細胞数と生存期間 とに有意な関連のあること，そしてまた抗白血 病剤の種類により減少動㦔に差のあることを報 告している。ただ正周らの報告は抗白血病剂の 単版投与によるものであり，作用機序の異なっ た薬剂を併用し，かつ投与量，投与期間の異な った多剤併用療法例 ${ }^{23.24)}$ では, 第二相の開始日を 画一的に設定することには無理があり，第一相 と第二相を含めた減少曲線が必要とされよう。 今回減少曲線の作成に当たっては, 実験腫演に おける腫湯減少動態が逆 S字状曲線を描くこと, 第二相の減少様式を 2 次曲線に近似し得ること などから減少速度の変化に着目し，前述した方 法を考案したわけであるが，作成された減少曲 線はその決定係数からみても実測値をよく反映 するものであった。この減少曲線によれば化学 療法後, 骨髄内白血病細胞は次第に減少速度を 增し, 最大減少速度に達した後，漸時減少速度 を低下させ減少停止に至ることが確認された。 またこの減少曲線は白血病細胞の生物学的特性
を含めた薬隹に対する感受性によって規定され るものと考之られるが, 具体的には白血病細胞 の増殖速度, 細胞周期など細胞側要因, 抗白血 病剂の作用機序，あるいは投与スケジュールと いった薬剤要因などによって規定されることが 予想される、このことから考えると第一相は， 薬剂の殺細胞効果が徐々に発現し, 白血病細胞 の減少速度が加速され最大減少に達するまでの 期間，すなわち白血病細胞に対する薬剤感受性 が抵抗性を上回る期間と考えられ，第二相は減 少速度が徐々に低下する期間，すなわち減少に 対する抑止力が働いていることを意味する. 特 に減少を制止する要素は,「すでに治療開始前上 り存在する自然耐性（抵抗性）細胞集団」,「細 胞周期と薬剂感受性の関係において殺細胞効果 を逃れた細胞集団」「「早期に薬戍耐性を獲得し た細胞集団」の存在とその増殖に起因するもの と考えられ，第二相の減少加速度はこれら細胞 集団が存在することを示す一つの指標となるも のと考えられる.

今回著者は骨髄内白血病細胞減少動態と治療 効果, 病型, 寛解導入療法との関係についてま ず検討したが， CR 例，NR 例で減少曲線を解 析した結果, 第一相ではその期間が CR 例で長 い傾向にあったが, 平均減少加速度及び最大減 少速度については CR 例，NR 例で有意差はみ られず，第二相においてはその期間と平均減少 
加速度に著明な差が認められた。すなわち CR 例 において最大減少速度に達した後も減少に対す る抑止力が小さく，より長期間白血病細胞の減 少が続くことが確認された。従って CR 例では 堿少停止日も遅く, 最終的に残存白血病細胞数 も NR 例に比べ有意に少なかった，逆にこのこ とはNR例においては自然あるいは治療早期に 薬剂耐性を獲得した白血病細胞の populationが 多く，減少に対する抑止力が大きいことを意味 するものと考之られる.しかし，第一相の平均 減少加速度, 最大減少速度は CR 例, NR 例に 有意差なく, 治療開始初期の減少動態一治療早 期に存在する感受性細胞集団一が最終的な治療 効果を反映することは少ないのではないかと考

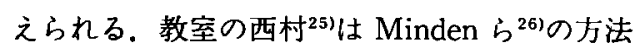
を用いて Leukemic blast progenitor 由来一次 コロニーを形成し，その形成能を経時的に観察 することによって,「コロニー数最高値からの50 \%減少までの日数」が骨髄内白血病細胞減少曲 線における第二相平均堿少加速度と正の相関関 係を示すことを報告している. Leukemic blast progenitor が一定の分裂の後死滅するとすれば コロニ一数は最高值に達した後急速に減少する が引引き続き分裂（自己再生）を繰り返すとす ればコロニ一数の減少は緩やかであると予想さ れ, 西村 ${ }^{25}$ は「コロニ一数最高值からの50\%減少 日数」は Leukemic blast progenitor の自己再 生能の指標となるとしている。このことからす れば第二相平均減少加速度, 寸なわち白血病細 胞減少に対する抑止力は一つには自己再生能の 高い細胞群によって形成されているものと考之 られ，より密度の高い治療効果を得るためには 自己再生能の高い細胞集団への対応一薬剂選択, 投与量, 投与スケジュールーが必要とされるも のと考えられる.

つぎに病型別, 寛解導入療法別に白血病細胞 の減少動態について解析したが, 各病型間での 比較では特に差は認められなかった。

また，寛解導入潦法別に各パラメーターを比較 したが、各療法間に差は認められなかった。す でに正岡ら $201 は \mathrm{DNR}, 6-\mathrm{MP}$, ara-C, NCSな ど各種抗白血病郕を単独で使用した場合の第二 相における減少速度と減少期間につき検討した
結果, 最大減少速度は DNR, NCS $>$ ara-C $>6$ -MP，減少期間は6-MP $>$ ara-C, DNR $>$ NCS であったとしている.今回の検討から NCMP 療 法, DCMP 療法, BHAC-DMP 療法, AC 療 法, BHAC-AMP 療法, DCV 療法間には差は 認められなかったことについては，今回の減少 曲線が多剂併用療法での減少動態を絵合的に把 握するため考案したものであることによると考 えられるが, 对象症例のほとんどが抗癌性抗生 物質十代謝拮抗剤あるいは phase non-specific drug + phase specific drug といった組合せで治 療されており，減少曲線はこれら抗白血病郕の 基本的併用効果を示したものと解釈される.ま た化学療法の施行に際しては当然のことながら 正常骨髄細胞の減少が認められ, 通常 CR 例で は骨髄抑制を受けた後, 白血病細胞より正常骨 髄細胞の方が早く回復する。このことは正常細 胞の細胞回転時間が白血病細胞より早いことに よるが27.28), NR 例や再発難治例においては白血 病細胞の方がより早期に增殖することが臨床上 しばしば経験される。このことはNR例におい てはより強い正常骨髄細胞への影響が関与する のではないかといった問題を一面では提起する が, この点につき骨髄内赤芽球減少曲線から検 討した結果, CR 例でむしろ第二相の日数が長い ことが注目された。このことは寛解導入療法に 際し高度の骨䯣低形成状態を得るへく薬剤の追 加投与がなされたことによると考えられるが， 少なくとも初回寛解導入においては白血病細胞 集団を targetとしたより強力な治療が必要なこ とをあらためて示㖫するものと考えられる。た だそのためには単に薬凨の intensity を高め るのみでは治療効果は期待できないことは言う までもなく，より有効な薬戍の開発はもとより， G-CSFをはじめとしたサイトカインの先行投与 によって白血病細胞を薬剤感受性の高い分裂增

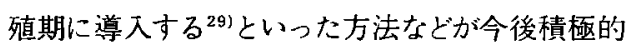
に検討されてゆく必要があろう。

巳て, 化学療法は「宿主一腫㿋一薬剂」の相 関において検討される必要があることは言うま でもない。これまで白血病寛解率に及ぼす宿主 要因としては加齢の問題が注目され，一般に高 齢者 ANLL では CR 率が非高齢者に比し低值 
とされている30-32).このことは加跲による宿主 予備能の問題も一つの要因として想定されるが, 白血病細胞の減少動態に非高粭者との間に差が 存在するのかといった問題が摍主要因も加味し た腫富要因として注目される。今回この点に関 し骨髄内白血病細胞減少曲線の面から高歯者群 と非高路者群とに分けて検討したところ, CR 例 で高跉者群において第一相の期間が長く，最大 減少速度が低值であった.これは高柃者群で抗 白血病戍の intensity が弱かったことによるも のと考之られるが，その他のパラメーターには $\mathrm{CR}$ 例，NR 例ともに違いは見い出せなかった。 このことは高秢者 ANLL の低 CR 率の要因と して薬荗感受性をはじめとした白血病細胞の生 物学的特性の関与は比較的少なく, 各種臟器の 予備能をはじめとした宿主側要因すなわち(1)化 学療法に対寸る骨咀予備能の低下, (2)肝腎機能 の低下に起因した pharmacokinetics の変化と 薬剂副作用の增強，(3)免疫力の低下による易感 染性などが主たるものと考えられ, 今後, $\mathrm{CR}$ 率 の向上に際してはより完全な補助療法を前提と し, 非高齢者におけると同様の化学療法の施行 が必要と考えられる。

すでに周知の如く，急性白血病の治療は完全 寬解率のみでなく，長期生存率ひいては治痖率 の向上を目指すものでなくてはならない，急性 白血病の長期子後を規定する因子についてはこ れまでにも検討されてきたが32,33)，今回作成した 骨䯠内白血病細胞減少曲線加寛解導入療法中 の白血病細胞の減少動態が予後にどのように関 与するかについて検討を行った，白血病細胞の 減少動態は CR 例, NR 例で明らかに異なり, 特に $\mathrm{CR}$ 例においては減少の抑止力と考之られ る第二相の減少加速度が NR 例に比べ極めて小 さいことが特徴的であったが, 予後との関連に おいても長期寛解群では第二相平均減少加速度 が低值であり，逆に第二相平均減少加速度が高 値の症例では CR 期間, 生存期間ともに短い傾 向にあった。すでに述べた如く第二相平均減少 加速度は減少抑止力に相当し，この減少抑止力 は一つには薬剤抵抗性を示す白血病細胞集団に よって構成されるものと考之られるが, 今回の 成績はこれら初期に残存する白血病細胞集団が
予後に対しても影響を与えることを示すもので あり，治痛を指向した治療体系の確立に対し極 めて重要な情報を提供するものと思われる.す なわち治瘾を指向した治療体系を考之る場合, 白血病細胞の減少はいずれの症例においても直 線的でなく減少抑止力によって形成される第二 相が存在することに注目する必要があり, “Total cell kill”9)を達成させるには,まず初回宽解導入 において薬剤耐性を獲得していない細胞群を可 及的に減少させ，さらに薬郕抵抗性を持った残 存白血病細胞集団（第二相白血病細胞集団）を 撲滅させるため寛解導入後の早期に交叉耐性の ない薬剂を含めた強力な寛解後療法 ${ }^{11-13)}$ が必要 と考えられる.また、これらの第二相の白血病 細胞集団は自己再生能の強い細胞集団と考之ら $れ^{25)}$, 宽解後早期化学療法においては自己再生能 を持つ白血病細胞に対してより効果的に殺細胞 効果を発揮する ara-Cなど ${ }^{23)}$ を積極的に導入す る必要があるものと考之られる．現在，わが国 では寛解導入療法においては individualized therapy ${ }^{16)}$ ，すな放ち治療効果を治療中に判定し， 一定の target point に持ち込むまで薬戍を追加 投与する治療法がひろく用いられているが，寛 解後早期化学療法においては白血病細胞を target とした individualized therapy はなされて いない，今後個々の症例で骨髄内白血病細胞減 少動態を解析することによって寛解後早期化学 療法の開始時期, 選択薬剂, 投与量等の決定が より的確になされてゆくものと考えられる。

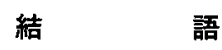

急性非リンパ性白血病（ANLL）寞解導入療 法中の骨娟迶内白血病細胞及び正常骨䯣細胞（赤 芽球）の減少動態を解析する目的で，減少曲線 として 4 次関数を適用し，第一相（減少開始か ら最大減少まで）の期間及び平均減少加速度, 第二相（最大減少から減少停止まで）の期間及 び平均減少加速度, 最大減少速度, 減少停止日, 減少停止時白血病細胞数の 7 パラメーターを設 定し, 治療効果, 病型, 寛解導入療法, 年齢, 予後との関連について検討した. その結果.

(1)治療効果別骨髄内白血病細胞減少曲線の検 討では，CR 例において有意に，第一相，第二相 
の期間が長く，第二相平均減少加速度が小さく， 残存白血病細胞が少なかった。

(2)病型別骨髄内白血病細胞減少曲線の㭘討で は，病型間に各パラメーターの差は認めなかっ た.

(3)治療法別骨㖪内白血病細胞隇少曲線の榆討 では，治療法間に各パラメーターの差は認めな かった.

(4)年齢別骨䯣内白血病細胞減少曲線の検討で は, CR 例の高齢者群で有意に第一相の期間が長 く，最大減少速度が低值であったが，その他は 高齢者と非高齢者群間に各パラメーターの差を 認めなかった。

(5)治療効果別骨䯣内赤芽球減少曲線の検討で は， CR 例で第二相の期間が有意に長かったが， その他のパラメーターに差は認めなかった。

(6)年齢別骨髄内赤芽球減少曲線の検討では, 高齢者群と非高粭者群間に各パラメーターに差 は認めなかった。
(7)骨㖪内白血病細胞減少曲線と予後との関連 を検討した結果, CR 例において第二相平均減少 加速度が大きい症例で $\mathrm{CR}$ 持続期間，生存期間 共に短い傾向を認めた。

以上の結果を得たが，今回作成した骨䯑道内白 血病細胞減少曲線は寞解導入療法中の白血病細 胞減少動態をよく反映し，治療効果及び予後と の関連において，特に治療抵抗性細胞集団の動 態について貴重な情報を提供するものであり， 白血病治癒を指向した治療体系の確立に寄与す るものと考えられた。

稿を終えるにあたり御指導，御校閲を睗った恩師 木村郁郎教授に深謝するとともに，終始想切なる御 指導と御助言を頂いた高橋功講師, 大本英次郎助手 に感謝の意を表する。

本論文の要旨は第49回日本血液学会総会 (東京), 第32回日本血液学会中国四国地方会 (高松) におい て発表した。

1) Ohno R, Yokomatu S, Okamura M, Nagai T, Kitaori K, Ito T, Takeo T, Suguura I, Yano K, Ito $\mathrm{Y}$, Kataoka T, Hamaguchi M, Adachi K, Tanimoto M, Ogura M, Morishita Y, Morishima $\mathrm{Y}$, Kawashima K, Minami S, Kodera $\mathrm{Y}$ and Sato $\mathrm{H}$ : Intensive individualized induction therapy with behenoyl cytarabine, daunorubicin and 6-mercaptopurine followed by intensive consolidation including intermediate-dose continuous cytarabine, mitoxantron, etoposide and vinca alkaloids in acute myeloid leukemia in adults. Int J Hematol (1991) 54, 487-493.

2）高橋 功, 稲垣登稔, 仲田浩之, 西村正隆, 林 直樹, 関籍典子, 野中研一, 竹内 誠, 長田 建, 松崎敏 郎, 福田俊一，中村 達，村瀬敏夫，木村郁郎：成人急性リンバ性白血病の治療成績. 臨床血液 (1989) 30, $1167-1170$.

3) Ellison RR, Holland JF, Weil M, Jacquillat C, Boiron M, Bernard JF, Sawitsky A, Rosner F, Gussoff B, Silver RT, Karanas A, Cuttner J, Spurr CL, Hayes DM, Blom J, Leone LA, Haurani F, Kyle R, Hutchison JL, Forcier RJ and Moon JH : Arabinocyl cytosine : A useful agent in the treatment of acute leukemia in adults. Blood (1968) 32, 507-523.

4) Boiron M, Jacquillat C, Weil M, Tanzer J, Levy D, Sultan C and Bernard J : Daunorubicin in the treatment of acute leukemia. Lancet (1969) 1, 330-333.

5) Aoshima M, Tsukagoshi S, Sakurai $Y$, Ohishi J, Ishida $T$ and Kobayashi H : Antitumor activites of newly synthesized $\mathrm{N}$-acyl-l- $\beta$-arabinofuranosyl-cytosine. Cancer Res (1976) 36, 2726-2732.

6) Hori $S$, Shirai M, Hirano $S$, Oki $T$, Inui $T$, Tsukagoshi $S$, Ishizuka $M$, Takeuchi $T$ and Umezawa $\mathrm{H}$ : Antitumor activity of new-anthracycline antibiotics, aclacinomycin-A and its analogs, and their toxicity. Gann (1977) 68, 685-690.

7 ）三比和美，小川一誠，木村郁郎，大獎泰亮，山田一正，正周 徽，涌井 昭，目黑安定，水井清保，大谷照 
夫，度田 秷，古川 敏，小林政英，大野竜三，山本正彦、斉藤達雄：治療抵抗性白血病に対する Mitoxantrone $の$ Phase II study. 癌と化学撩法 (1989) 13, 3020-3021.

8 ) Sauter C, Fehr J, Frick P, Gmuer J, Honegger H and Martz G : Acute myelogenous leukemia. successful treatment of relapse with cytosine arabinoside, VP16-213, vincristine and vinblastin (A -Triple V). Eur J Cancer Clin \& Oncol (1982) 18, 733-737.

9) Skipper HE: Experimental evaluation of potential anticancer agents XIII, On the criteria and kinetics associated with "curability" of experimental leukemia. Cancer Chemother Rep (1964) 35, $1-11$.

10) Uzuka $Y$, Liong SK and Yamagata $S$ : Tretment of acute non-lymphoblastic leukemia using intermittent combination chemotherapy with daunomycin, cytocine arabinoside, 6-mercaptopurine and prednisolone-DCMP two step therapy. Tohoku J Exp Med (1976) 118, 217-225.

11) Goldie JH, Coldman AJ and Gudauskas GA : Rationale for the use of alternating non-cross-resistant chemotherapy. Cancer Treat Rep (1982) 66, 439-449.

12) Wolff SN, Marion J, Stein RS, Flexner JM, Lazarus HM, Spitzer TR, Phillips GL, Herzig RH and Herzig GP : High-dose cytosine arabinoside and daunorubicin as consolidation therapy for acute non-lynphocytic leukemia in first remission : a pilot study. Blood (1985) 65, 1407-1411.

13) Weinstein HJ, Mayer RJ, Rosental DS, Camitta BM, Coral FS, Nathan DG and Frei E III : Treatment of myelogenous leukemia in children and adults. N Engl J Med (1980) 303, 473-478.

14) Ohono R, Tomonaga M, Kobayashi $T$, Kanamaru A, Shirakawa $S$, Masaoka $T$, Omine M, Oh H, Nomura T, Sakai Y, Hirano M, Yokomaku S, Nakayama S, Yoshida Y, Mimura A, Morishima Y, Dohy H, Niho Y, Hamajima N and Takaku F : Effect of granulocyte colony stimulating factor after intensive induction therapy in relapsed or refractory acute leukemia. $\mathrm{N}$ Engl J Med (1990) 323, 871-877.

15）元吉和夫, 高久史麿, 正岡 徹, 宮崎 保, 柴田 昭, 小峰光博, 木村 健, 三浦恭定, 古沢新平, 阿部 師, 服部理男, 野村武夫, 蔧口秀昭, 小川一誠, 下山正德, 衣笠恵士, 富永 健, 出浦喜丈, 太田和雄, 白川 茂, 田口 男, 垂井清一郎, 安富正幸, 中山志郎, 木村郁郎, 土肥博雄, 三好勇夫：低又は無顆粒球症に对する P-100 (CSF-HU) の投与効果. 日本癌治療学会誌 (1988) 23，2760-2768.

16）宇榢善郎，齐藤淑子：成人急性非リンパ性白血病の治瘾的治療法。臨床血液（1989）30，1163-1166.

17) Norton $L$ and Simon $R$ : Tumor size, sensitivity to therapy, and design of treatment schedules. Cancer Treat Rep (1977) 61, 1307-1317.

18) Bennett JM, Catovsky D, Daniel MT, Flandrin G, Galton DAG, Gralnick HR and Sultun C: Proposals for classification of the acute leukemias. French-American-British (FAB) Co-operative group. Br J Haematol (1976) 33, 451-458.

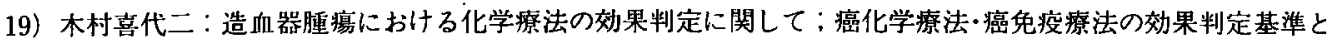
制澏剤開発，斉藤達雄編，サイエンスフォーラム，東京 (1981) pp 54-66.

20）正岡 徹：急性白血病治療と白血病細胞数の変動. 臨床血液（1976）17，707-715.

21) Hart JS, Shimakawa S, Trujiro J and Frei E III : The mechanism of induction of complete remission in acute myeloblastic leukemia in man. Cancer Res (1969) 29, 2300-2307.

22) Presant CA, Vietti $T$ and Valeriote $F$ : Kintics of both leukemic and normal cell population reduction following 5-Azacytidine. Cancer Res (1975) 35, 1926-1930.

23) Clarkson BD, Dowling MD, Gee TS, Cunningham JB and Burchenal JH : Treatment of acute leukemia in adults. Cancer (1975) 36, 775-795.

24) Keating MJ, Smith TL, Mccredie KB, Body GP, Hersh EM, Gutterman JU, Gehan E and Freireich 
EJ : A four year experience with anthracycline, cytocine arabinoside, vincristine and predonine combination chemotherapy in 325 adults with acute leukemia. Cancer (1981) 47, 2779-2788.

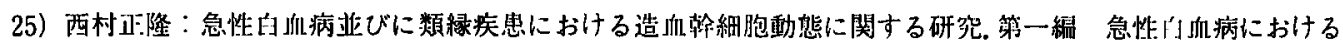
Leukemic Blast Progenitors 由来コロニー形成能並びに形成パターンの検討。岡山医誌 (1991) 103，1147 $-1158$.

26) Minden MD, Buick RN and McCclloch EA : Separation of blast cell and $T$-lymphocyte progenitors in the blood of patients with acute myeloblastic leukemia. Blood (1979) 54, 186-195.

27) Gavosto F, Maraini G and Pileri A : Proliferative capacity of acute leukemic cells. Nature (1960) 187, 611-612.

28) Clarkson B, Ohkita T, Oka $\mathrm{K}$ and Fried J : Studies of cellular proliferation in human leukemia I. Estimation of growth rate of leukemic and haematopoietic cells in two adults with acute leukemia given single injection of tritiated thymidine. J Clin Invest (1967) 46, 506-529.

29) Hanazono Y, Miyazono K, Patio YF, Taketazu F, Chiba S, Miyagawa K, Hirai H, Sakamoto S, Miura Y, Yazaki Y and Takaku F : Treatment of acute nonlymphocytic leukemia by combina. tion of recombinant human granulocyte colony-stimulating factor and cytotoxic agents : A report of six cases. Int J Hematol (1992) 55, 243-248.

30）高橋 功, 原 雅道, 高岡和子, 植田育筧, 福本光去, 稲垣登稔, 滝沢道弘, 大本英次郎, 小田康広, 藤本 修逸，遠藤 裕, 頼 敏裕, 厚井文一, 喜多嶋康一, 木村郁郎, 真田 浩, 時岡正明, 依光聖一：高齢者血 液疾患に関する検討。第三報：高齢者急性非リンパ性白血病の化学療法効果. 日老医誌 (1984) 21, 14-19.

31) Keating MJ, Smith TL, Geham EA, McCredie KB, Bodey GS and Freireich MD : A prognostic factor analysis for use in development of predictive models for response in adult leukemia. Cancer (1982) 50, 457-465.

32) Passe S, Mike V, Mertersmann R, Gee TS and Clarkson BD : Acute nonlymphocytic leukemia Cancer (1982) 50, 1462-1471.

33) Buick RN, Chang LJ-A, Messner HA, Curtis JE and McCulloch EA : Self-renewal capasity of leukemic blast progenitor cells. Cancer Res (1981) 41, 4849--4852. 


\section{Leukemic cell destruction kinetics in bone marrow Makoto TAKEUCHI \\ Second Department of Internal Medicine, Okayama University Medical School, \\ Okayama 700, Japan \\ (Director Prof. I. Kimura)}

An equation was developed to describe the kinetics of leukemic cell destruction in bone marrow during induction chemotherapy for acute nonlymphocytic leukemia $\left(\log Z=K_{1} \mathbf{t}^{4}+\right.$ $K_{2} t^{3}+K_{3} t^{2}+K_{4}$, where $Z=$ leukemic cell number, $t=$ time, and $K=a$ constant). The leukemic cell destruction curve was biphasic ; phase $I$ was the period from the initiation of a decrease in cells to the maximum velocity of the decrease, and phase II was the subsequent period to the cessation of decrease. The following parameters were established : duration and acceleration of decrease in phases I and II, maximum velocity of decrease, duration of reduction, and residual volume of leukemic cells.

1. Patients who achieved CR showed a longer duration of phases I and II, a lower acceleration of the decrease in phase II, and smaller residual leukemic cell volume than patients who did not achieve CR. there were no significant differences of parameters related to FAB classification, type of induction therapy, or the age of the patients.

2. This equation could be adapted to explain erythroblast kinetics during induction chemotherapy. There were no significant differences of the parameters with respect to the effect of induction therapy and patient age.

3. Patients with high acceleration of the decrease in phase II had a short duration of CR and survival.

The leukemic cell destruction curve was thought to be useful not only for evaluation of the effect of induction therapy, but also for establishment of post-remission chemotherapy. 